\title{
Islamic Law Perspective on Civil Servant Divorce Process
}

\author{
Mus Mualim 1*, Muhammad Syarif Hasyim ${ }^{2}$, Muhammad Akbar ${ }^{3}$
}

1 Islamic Family Law Department, Postgraduate, Institut Agama Islam Negeri Palu

2 Islamic Family Law Department, Postgraduate, Institut Agama Islam Negeri Palu

${ }^{3}$ Islamic Family Law Department, Postgraduate, Institut Agama Islam Negeri Palu

\begin{abstract}
The aim of this study is to understand Islamic Law Perspectives on the divorce that is carried out by the government employees in Palu. This study used a qualitative field research. The research procedure that produces descriptive data in the form of writing and attitudes that can be observed from the subject itself. The data sources were obtained from primary and secondary data collected by observation, interviews and documentation. The data analysis techniques used were inductive and continuous using data reduction, data presentation and drawing conclusions or verification. The results show that the government employees who will conduct a divorce must obtain permission from the competent superior, which is then processed at the Regional Civil Service Agency, then the application process or divorce suit will be continued at the Palu Religious Court Class I A. As for legal review Islam regarding the divorce process of the State Civil Apparatus (ASN) is in accordance with Islamic law based on the word of Allah in QS An-Nisaa: (4): 59 and the complicating principle contained in the divorce process of the State Civil Apparatus (ASN) is in line with Islamic law as in the hadith of the prophet, namely From Ibn Umar. He said that Rasulullah Saw. has said, "that which is lawful which God hates most is divorce". By understanding this hadith, Islam encourages the realization of a happy and eternal marriage, this is also contained in Law 1 of 1974 concerning the purpose of marriage, namely to form a happy and eternal family (household) based on one Godhead.
\end{abstract}

ARTICLE

INFORMATION

\section{Keywords:}

Islamic law, government

employees, divorces 


\section{Introduction}

Every shari'a has a purpose or is called maqasid al-shari'ah. ${ }^{1}$ The purpose of the marriage is to form a happy and eternal family. ${ }^{2}$ In addition, the purpose of marriage, according to Islam, is to carry out religious orders in establishing a harmonious and happy family. This can be achieved when they use the principle of forever marriage, not with a certain time limit. That is why the marriage in Islam must be based on the willingness of the heart. The stability of the household and the continuity of husband and wife life are the main goals of marriage, and this is very much considered by Islamic law. ${ }^{3}$

In Indonesia, a marriage is valid if it is carried out according to the religion and beliefs held by a husband and wife, and is recorded according to the applicable legislation. To realize a happy and eternal marriage is certainly not easy, there are many factors that can hinder it, one of which is conflict within the family which can reduce harmony. As a result, an agreement emerged not to maintain the household and, instead, chose to divorce.

Although it is permissible, divorce is an undesirable condition for married

1 Formore study on Maqasid al-Shariah, see also Rusli Rusli, "Al-Juwaini Dan Konsep Maqashid Syari'ah Telaah Kitab Al-Burhan Fi Usul Al-Fiqh," Istinbath: Jurnal Hukum 9, no. 2 (2013).; See also Rusli Rusli, “Wahhabi Salafism's View on Maqasid Al-Syariah," Al-Manahij: Jurnal Kajian Hukum Islam 8, no. 2 (2014): 167-180.

2Sudarsono, Hukum Perkawinan Nasional, (Jakarta: PT. Rineke Cipta, 1991), 7.

${ }^{3}$ Abdul Rahman Ghozali, Figh Munakahat, (3rd Edition, Jakarta:Kencana, 2008), 22; couples. Divorce is considered a failure, because in it there is a dissolution of marriage ties that were previously considered sacred. Divorce is the breaking of family ties caused by one or both of them deciding to leave each other. Thus, both husband and wife stopped fulfilling their obligations and carrying out their roles in the household. ${ }^{4}$

Many factors encourage married couples to divorce, one of which can be caused by a lack of awareness to fulfill their rights and obligations as a couple in the household. In Article 19 of Government Regulation Number 9 of 1975 concerning marriage, it is stated that among the reasons for divorce are that one of the parties commits adultery, gambling, leaving a partner, being sentenced to prison, and domestic violence. ${ }^{5}$

Article 39 of the Marriage Law also states that divorce can only be carried out in front of a court session, after the court has tried and failed to reconcile the two parties. In addition, there must be sufficient reason for the divorce. Divorce can happen to anyone, including state officials, artists, and state civil servants (ASN).

Even in Palu, it is not uncommon for state civil servants to divorce, especially from 2016 to the end of 2019.

${ }^{4}$ Anik Farida et.al, Perempuan dalam Sistem Perkawinan dan Perceraian di Berbagai Komunitas Adat (Jakarta: Balai Penelitian dan Pengembangan Agama Jakarta, 2007), 17; See also Rusli Rusli, "Hermeneutical Reading of Țalāq," HUNAFA: Jurnal Studia Islamika 12, no. 2 (2016): 209-229.

${ }^{5}$ Government Regulation, Nomor 9 Year 1975, Article 19.

e-ISSN: $2715-4580$ p-ISSN: 2715-8268 
Why and how they divorced, is the reason for writing this paper, from the perspective of Islamic law.

\section{Literature Review}

\subsection{Divorce in Positive Law and Islamic Law}

Divorce is part of marriage; in the sense that divorce exists because of marriage; if there is no marriage, there is no divorce. Therefore, marriage is the beginning of both husband and wife's life, and divorce is the end of life as husband and wife. ${ }^{6}$ If it turns out that the marriage cannot continue for some reasons, then there must be a way out. Letting both parties not break the marriage is a torture, and the best solution is divorce. ${ }^{7}$

As stated in the marriage law, the causes of divorce are death, divorce and court decisions. Therefore, maintaining a harmonious household relationship between husband and wife is very important. ${ }^{8}$ Therefore, the termination of marriage between husband and wife due to the will of both, which is caused by the factors mentioned in the legislation, is called divorce, whether it is because the husband and wife violated their rights

${ }^{6} \mathrm{M}$ Djamil Latif, Aneka Hukum Perceraian di Indonesia (Ghalia: Indonesia, 1985), 27.

7R. Soetojo Prawirohamidjojo, Sejarah Perkembangan Hukum Perceraian di Indonesia Belanda (Surabaya: Airlangga University Press 1996), 30.

8 Sukaenah, Sukaenah, Rusli, Rusli, \& B, M. Taufan. (2020). The Effectiveness of Indonesia Supreme Court Regulation Number 1 Year 2016 Concerning Mediation of Marriage Disputes International Journal of Contemporary Islamic Law and Society, 2 (1), 63-80. and obligations, or because of other problems that led to the breakup of the marriage. ${ }^{9}$

In Indonesia, regulations regarding marriage include, among others, Law No. 1 of 1974 concerning Marriage and the Compilation of Islamic Law (KHI) for Indonesian citizens who are Muslim. However, there is also a special regulation issued by the government, which regulates the marriage and divorce of Civil Servants, namely PP No. 10 of 1983.

The statutory provisions governing the dissolution of marriages can also be found at Burgerlijk Wetboek Indonesia (BWI). The marriage referred to in BWI is the termination of the marriage bond carried out by the state, by a civil registry official or other authorized officer in his field. As stated in Article 38 of Law No. 1 of 1974, marriages can be terminated due to death, divorce, and by court decisions. Therefore, if a husband and wife want to divorce, they must go through the procedures as regulated in the BWI. To be able to initiate a divorce procedure, prior permission must be obtained from the head of the district court. Thus, it can be concluded that in the matter of divorce, BWI strongly adheres to the principle of the immortality of marriage. ${ }^{10}$

${ }^{99}$ See Rusli Rusli, “An Analysis of Islamic Feminism in Indonesia: Reconstruction of Islamic Legal Issues on Gender Relations," Hunafa: Jurnal Studia Islamika 3, no. 1 (2006): 1-12.; See also Rusli Rusli, Islamic Feminism: Responses of Muslim Feminists to Gender Inequality in Indonesia (Palu: Irshed Press, 2006).

${ }^{10}$ Article 2 of Civil Code.

e-ISSN: 2715-4580 p-ISSN: $2715-8268$ 
Islamic law is the law that comes from Allah, and is part of Islam. ${ }^{11}$ Islamic law not only regulates the relationship between man and God, but also regulates the human relationship between man and himself, and the relationship between man and the natural surroundings. Islamic law is a set of rules revealed by Allah and the Sunnah of the Prophet regarding the behavior and attitudes that are recognized and believed, and implemented by all Muslims. ${ }^{12}$

In Islamic law, divorce is an act that is allowed, but not liked by Allah. Divorce is a solution if the marriage can no longer be maintained. However, in Islamic law, there are rules related to this rule. And in Islamic law, divorce can also be divided into talaq and khulu'. Talaq or divorce is carried out by the husband either because of his own will and for certain reasons, while $k h u l u^{\prime}$ is a wife filing a divorce suit against her husband.

\subsection{Reason of Divorce from Islamic Law's Perspective}

One of the causes of divorce in Islamic law is nusyuz, which etymologically means "disobedience". In terminology, it means "a wife, who opposes her husband, ignores orders and hates him." 13

11 See Rusli Rusli, Nalar Fikih Tradisionalis Progresif: Analisis Terhadap Epistemologi Ibrahim Hosen, 1st ed. (Yogyakarta: Maghza Books, 2014).

${ }^{12}$ Abdul Ghani Abdullah, Pengantar Kompilasi Hukum Islam dalam Tata Hukum Indonesia (Jakarta: Gema Insani Press, 1994), 10.

${ }^{13}$ Tim Al-Manar, Fikih Nikah (Bandung: Syamil Cipta Media, 2007), 98.
Nusyuz or disobedience does not only occur on the wife's side, but also on the husband. Among the kinds of nusyuz done by husbands are staying away from his wife, being rude, not accompanying her, leaving his bed, and reducing his income. ${ }^{14}$

Another reason is the separation of beds, which in figh terms, is called al-hijr, which means "leaving, separating and not relating to the object in question". In terminology, it means a husband who does not touch his wife, does not talk to her, and does not have any relationship or cooperation with her. The separation (hijr) carried out by the husband is limitless, as long as it is deemed to be able to awaken the wife, as long as it does not exceed four consecutive months, because that period is the maximum limit that cannot be exceeded, according to the strongest opinion.

Islamic shari'a regulates the rule and method of dealing with disobedience of wife. A husband is not allowed to treat his wife arbitrarily. This is a kind of Islamic justice to the umma, especially to wife. The scholars of madhhab agree that the justified beating is a blow that does not hurt, injure, break bones, and damage the face. According to Muhammad Ali al-Shabuni and Wahbah al-Zuhaili, the parts of human's body that must be avoided from beatings are the face, stomach, and other parts that can cause death.

The dissolution of a marriage due to faskh may occur due to an error that occurred at the time or after of the

\footnotetext{
${ }^{14}$ Ali Yusuf As-Subkhi, Figh Keluarga (Jakarta: Amzah, ny), 317.

e-ISSN: 2715-4580 p-ISSN: 2715-8268
} 
contract. The forms of error in the time of the contract include, for example, husband and wife having a kinship, sibling relationship, marriage due to coercion, and fraud in the dowry. The forms of error after the marriage contract include, for example, apostasy after divorce, physical disability, the husband lost source of income, and the wife impatience of the recovery of the husband's economic life. Faskh is carried out if one party feels cheated and submits a request for a decision to the religious court. ${ }^{15}$

\subsection{Economic Factor as a Cause of Divorce}

Family economy is related to family efforts in fulfilling unlimited family needs faced with limited resources. One of the problems that are often faced by married couples in the household is economic problems. Family economy is related to the fulfillment of material needs. In practice, this sometimes economic family faces difficulty, even in critical situations, it stops. Failure to meet economic needs in the household can trigger new problems, which sometimes even lead to divorce. ${ }^{16}$

${ }^{15}$ Amir Syarifudin, Garis-garis Besar Figh (Jakarta: Prenada Media Group, 2003), 134-135.

${ }^{16}$ Ahmad Muhammad al-Sissal, et.al, Sistem Prinsip dan Tujuan Ekonomi Islam (BandunDivorce is the last alternative in solving family problems. In Indonesia, this issue is regulated in Law Number 1 of 1974 concerning Marriage and the Compilation of Islamic Law. In Article 34 of the Marriage Law Number 1 of 1974 concerning Marriage paragraph 3 and Complications of Islamic Law Article 77 paragraph 5 it is stated that "If a husband or wife neglects their obligations, each of them can file a
The husband's income cannot meet the needs of the family if his income is low. The husband's low income can be defined as not meeting basic needs, or income can be categorized as low if the income is not sufficient to meet the most basic needs of life, such as food, clothing, shelter, and others. ${ }^{17}$

There are many opinions regarding the minimum limit for providing a living from a husband to his wife. This difference of opinion is based on the standard provisions related to the determination of the size of the income. The first opinion, Imam Ahmad stated that its measurement is the socioeconomic status of husband and wife together. If husband and wife have different social status, then the middle standard is taken between the two. The basis of this opinion is that the family is a combination of wife and husband; therefore, both are used as the basis for consideration in determining the standard of living.

The second opinion, Imam Malik stated that the amount of living is not determined by the Shari'a, but based on the circumstances of each husband and wife. These conditions vary based on differences in place, time, and circumstances. This is also Abu Hanifah's view. Due to the uncertainty of living, whether it is analogous to giving food in

lawsuit to the Religious Court". Violation of obligations in the household can not only be done by a husband, but also by a wife. Therefore, every couple must take care of each otherg: C.V Pustaka Setia, 1999), 9.

17Emil Salim, Perencanaan Pembangunan dan Pemerataan Pendapatan (Jakarta: Yayasan Idayu, 1980), 19. 
kafarat or giving clothes, the fuqaha agree that the provision of clothing has no limit and that the provision of food has a limit. 18

\subsection{Regulations of State Civil Apparatus Divorce}

Divorce is the last alternative in solving family problems. In Indonesia, this issue is regulated in Marriage Law Number 1 of 1974 and the Compilation of Islamic Law. In Article 34 of the Marriage Law Number 1 of 1974, paragraph 3 and the Complications, Article 77 paragraph 5 , it is stated that "If a husband or wife neglects their obligations, each of them can file a lawsuit to the Religious Court". Violation of obligations in the household can not only be done by a husband, but also by a wife. Therefore, every couple must take care of each other. ${ }^{19}$

The obligations of husband and wife have been regulated in Marriage Law Number 1 of 1974. The obligations are absolute or mandatory, while the standard of the fulfillment of these obligations depends on the ability of each party. If one of the parties neglects their obligations intentionally, then, according to the Marriage Law, it is an act of domestic violation.

Disputes that often occur in the household and differences of opinion between husband and wife, are one of

18Ibnu Rushd, Bidayat al-Mujtahid Wa Nihayat al-Muqtasid, Vol. 2 (Beirut: Dar al-Jil, 1989), 41.

19 Yunus, Haerunnisa, Rusli, Rusli, \& Abidin, Abidin. (2020). "The Concept of A Marriage Agreement in the Compilation of Islamic Law" Internationa Journal of Contemporary Islamic Law and Society, 2 (2), 35-45. the causes of conflicts that lead to divorce. The term 'divorce' is contained in Article 38 of Marriage Law Number 1 of 1974, which contains a clause that a marriage can be dissolved because of death, divorce, and on the court's decision. So, the term divorce legally means the dissolution of marriage, which results in the breakup of the relationship as husband and wife. ${ }^{20}$

In the marriage law, divorce is not prohibited, but its implementation is complicated. This means that divorce is allowed if the marriage cannot be maintained anymore, and also, it must be carried out before a court hearing. ${ }^{21}$ The principle of complicating the divorce process is based on the goal to maintain the purpose of marriage according to Article 1 of Marriage Law, namely to form a happy household, through inner and outer ties between a man and a woman based on the Oneness of God. ${ }^{22}$ In realizing the purpose of marriage, husband and wife must help and complement each other so that each can develop his or her personality in realizing spiritual and material wellbeing.

\section{Methodology}

\footnotetext{
${ }^{20}$ Muhammad Syaifuddin, et.al, Hukum Perceraian, $2^{\text {nd }}$ Edition (Jakarta: Sinar Grafika, 2014), 15.

${ }^{21}$ Abdul Manan, Aneka Masalah Hukum Perdata Islam Di Indonesia (Jakarta: Kencana, 2008), 9.

${ }^{22}$ Muhammad Syaifuddin, dkk, Hukum Perceraian cet. 2 (Jakarta: Sinar Grafika, 2014), 36. e-ISSN: 2715-4580 p-ISSN: 2715-8268
} 
This study uses qualitative approach, ${ }^{23}$ investigating the process of divorce for the government employee in Palu from Islamic law's point of view. This research was carried out in the office of the Regional Civil Service Agency and Relihious Court located in Palu. The location selection is based on a reason that this agency is a forum for the State Civil Apparatus and Religious Court of Palu is the executor of court session in the case of divorce of State Civil Apparatus who are Muslim.

Data were collected through observation, indepth interview with married counselors and couples who want to get married and written material. $^{24}$ Data analysis consists of several procedures such as reduction and verification techniques with various data sources. ${ }^{25}$ The reduced data is then analyzed reflecting on theoretical concepts used in this study. ${ }^{26}$

23 Nurdin, N., \& Yusuf, K. (2020). Knowledge management lifecycle in Islamic bank: the case of syariah banks in Indonesia. International Journal of Knowledge Management Studies, 11(1), 59-80.

https://doi.org/10.1504/ijkms.2020.105073

24 Nurdin, Nurdin. (2019). Knowledge Integration Strategy in Islamic Banks. In Almeida Helena \& Sequeira Bernardete (Eds.), The Role of Knowledge Transfer in Open Innovation (pp. 118138). Hershey, PA, USA: IGI Global.

25 Muslih, Imam, Nurdin, Nurdin, \& Marzuki, Marzuki. (2020). Effectiveness of Marriage Services Through Information System Management (SIMKAH) at Palu City Religious Court International Journal of Contemporary Islamic Law And Society, 2(1), 20-35.

${ }^{26}$ Iqbal, M., Rusli, R., \& Musyahidah, M. (2019). "Management Strategies of Professional Zakat Funds for Mustahiq Family Welfare By

\section{Result and Discussion}

\subsection{Divorce Process of State Civil Apparatus in Palu \\ Marriage Law has regulated the} provisions of marriage that apply to all citizens of Indonesia, including citizens with the status of civil servant. They are obliged to set a good example to the community and be an example as a good citizen in carrying out family life.

Eternal and happy marriage is certainly the dream of all families, and a happy family can play a role in preventing conflicts in society.27 However, it does not rule out the possibility of divorce in the course of domestic life. Therefore, for the State Civil Apparatus, marriage and divorce permits have been regulated. For the State Civil Apparatus (ASN) who will be doing divorce, they must obtain written permission in advance from the authorized official, that is, their superior.

For example, if the civil servant has an office in sub-district, it must go through Camat (head of sub-district) first, and then to the Regional Civil Service Agency to apply for a divorce permit. If the civil servant works in the Agency, he comes directly to the Regional Civil Service Agency (BKD) for divorce permit. For a civil servant who works as a teacher, he must first go to the Regional Education Office for divorce permit.

Amil Zakat Body." International Journal of Contemporary Islamic Law and Society, 1 (1), 39-51.

${ }^{27}$ For more details, see Rusli Rusli, "The

Role of Family in Preventing Social Conflict in Society From Islamic Perspectives," HUNAFA: Jurnal Studia Islamika 17, no. 1 (2020): 108-122.

e-ISSN: 2715-4580 p-ISSN: $2715-8268$ 
As $M$ said when taking care of divorce permit,

"In the first divorce process, at that time I was still worked in Kelurahan (Urban Village), and had to ask for a letter of recommendation from Camat (Head of Sub-District). After getting a letter of recommendation from Camat, then I went to the Regional Civil Service Agency to apply for a Divorce Permit. In the process, the summons was held three times for mediation, while the mediation effort was carried out from process of getting a letter of recommendation from Camat. After that, mediation was continued at the Regional Civil Service Agency, which in the mediation process, the respondent was not present until the third summons." 28

For civil servants who will apply for a divorce permit should compliment the following requirements:

1. Written application from the plaintiff.

2. Statement of willing to vivorce in writing from the defendant.

3. Record of examination from the plaintiff's Regional Working Unit

4. Photocopy of Family Card

5. Photocopy of Identity Card from the plaintiff and defendant

6. Photocopy of Marriage Certificate

If a civil servant applies for a divorce permit, but the requirements are not yet complete, then the authorized superior cannot accept the proposed divorce permit from the plaintiff. After

28 Interview with $\mathrm{M}$, a civil servant who did divorce, Palu, 20 November 2019. the plaintiff completes these requirements, the authorized superior will go through the stages of granting permission.

According to Dewi Asnita, a staff of Disciplinary Management, Regional Civil Service Ageny, Palu, "The authorized superior with the team checks the application by contacting the defendant to ensure the truth. If the defendant does not come after the second and third summons, the superior will make an official report on the absence from the summons and the teams that have been appointed are to take care of the case." 29

Furthermore, Asnita said, that the applicant and the plaintiff as well as the Regional Civil Service Agency must ensure the summons or news regarding the divorce case. The superior will analyze the examination process, whether it is appropriate or not to issue a divorce permit. If the superior feels it is possible to issue the divorce permit, the superior will issue a letter signed by the superior and both parties, or can be represented by the applicant or plaintiff, if the respondent or the defendant is not present. After that, the applicant or plaintiff takes the case to the Court to process the divorce proposal. ${ }^{30}$

State Civil Apparatus will be severely punished, as described in Government Regulation No. 53 of 2010, if:

29Interview with Dewi Asnita, staff of Disciplinary Management, Agency of Regional Employee, Palu, 20 Novemberi 2019.

${ }^{30}$ Interview with Dewi Asnita, staff of Disciplinary Management, Regional Civil Service Agency, Palu, 20 Novemberi 2019.

e-ISSN: 2715-4580 p-ISSN: 2715-8268 
a. They do divorce without obtaining prior permission from the authorized official or superior for the applicant/plaintiff.

b. They refuse to carry out the distribution of salaries and do not want to sign the payroll as a result of the divorce they are doing.

c. They do not report the divorce to the authorized official within a period of no more than one month after the divorce occurs.

d. The superior does not give consideration and permission to divorce suit, and to have more than one wife within a period of no more than three months after the official receives the request for notification of a divorce lawsuit.

e. An official does not give a decision on a divorce permit or provide a certificate of notification of a divorce suit, and make a decision on a request for permission to have more than one wife within a period of no later than three months after he received the permit or notification of a divorce suit. ${ }^{31}$

Civil Servants who do not obtain a permit for divorce beforehand from the official, and do not report their divorce within no later than one month from the start of the divorce, are qualified as breaking the law, specifically in the case of divorce, according to PP. 53 Year 2010.

${ }^{31}$ BKD Provinsi Sumatera Selatan, "Izin Perkawinan dan Perceraian Bagi PNS" in http://bkd.sumselprov.go.id/?nmodul=halaman \&judul=izin-perceraian-bagi-pns, Accessed: 23 February 2020.

\subsection{Alimony and Salary Distribution for State Civil Apparatus after Divorce}

The obligation to provide a living by the husband for his ex-wife and children is specifically regulated in Article 8 of the Government Regulation Number 10 of 1983, which has been amended by the Government Regulation Number 45 of 1990. If the divorce is carried out by a civil servant, the parents are responsible for their child. This is regulated in the Government Regulation Number 10 of 1983 concerning Marriage and Divorce Permits for Civil Servants, in Article 8, which reads:

1. If the divorce occurs at the will of a male Civil Servant, then he is obliged to give a half of his salary to support his ex-wife and children.

2. The distribution of salary, as referred to in paragraph (1), is one third for the male Civil Servant concerned, one third for his ex-wife, and one third for his children.

3. If there are no children from the marriage, then the part of the salary that must be submitted by a male civil servant to his ex-wife is half of his salary.

4. If the divorce occurs at the will of the wife, she is not entitled to a share of the income of her ex-husband. ${ }^{32}$

This was also experienced by A, who did not give his salary because his wife had left the house for two years

\footnotetext{
${ }^{32}$ Muhammad Syarifuddin, Sri Turatmiyah dan Annalisa Yahana, Hukum Perceraian ,(Jakarta: Sinar Grafika, 2014), 464-466. e-ISSN: 2715-4580 p-ISSN: 2715-8268
} 
without reason and approval from A. ${ }^{33}$ In another case, $\mathrm{M}$ as the applicant said, "When doing my first divorce, the distribution of salaries was only given to the child from the basic salary, and the process was carried out at the agency, at that time I was the plaintiff" ${ }^{34}$

According to Dewi Asnita, as the Disciplinary Management Staff of the Regional Civil Service Agency in Palu, in managing the distribution of salaries, the Regional Personnel Agency issues a decree for the distribution of salaries, but it must be with the knowledge of the plaintiff, after that the management is continued at the Financial Management Agency and salary treasurer. The allowance for children, it is only given until the child reachs 21 years old, and can be extended until the age of 25 years, if the child is still in school provided that he can show a statement from the school principal or rector in college, that the child is still in school or college. ${ }^{35}$

The ex-wife's right to share of the salary is not given if the divorce occurs because the wife is proven to have committed adultery, or the wife is proven to have committed cruelty or serious abuse both physically and mentally to the husband, or the wife is proven to be a drunkard, condensed, and gambler who is difficult to cure, or the wife is proven to has left her husband for two consecutive years without the

${ }^{33}$ Interview with A, a civil servant who was divorced, Palu, 23 June 2020.

${ }^{34}$ Interview with $\mathrm{M}$, a civil servant who was divorced, Palu, 20 November 2019.

${ }^{35}$ Interview with Dewi Asnita, 20 November 2019. permission of the husband and without a valid reason or for other reasons beyond his control.

If the divorce occurs at the will of the wife because of the husband's polygamy, or the husband commits adultery, or commits severe physical and mental abuse, or the husband is proven to be a drunkard, thief, or the husband is proven to have left his wife for two consecutive years without permission from the wife and without a valid reason or for other reasons beyond her control, then the wife's right to shareof her exhusband's salary is still given.

The salary treasurer can directly hand over part of the salary that is the right of to his ex-wife and children as a result of the divorce, and without waiting for the salary to be collected from her ex-husband who has divorced her. The ex-wife can also take part of her salary directly from the Salary Treasurer, or by using a power of attorney. With the Government Regulation Number 10 of 1983, civil servants cannot treat ex-wife arbitrarily, for example, in the case of divorce.

The judge's consideration in terms of salary distribution is that it is left to the relevant agency. ${ }^{36}$ In some divorce cases for civil servants, the judge, in practice, may decide for a husband, who is a civil servant, to support his wife only until 'iddah or waiting period, or until his ex-wife remarries.

\section{Conclusions}

36Wipress, Peraturan pemerintah tentang PNS, wacana intelektual, 2007, 336-337.

e-ISSN: 2715-4580 p-ISSN: $2715-8268$ 
Based on the previous description, it can be concluded that in the civil servant divorce process, there is a process that must be carried out, starting from administrative management at the Regional Civil Service Agency to the process of obtaining permission from the superior. Regarding the granting of divorce permits, it is in the hands of the authorized superior. After taking care of the Regional Civil Service Agency and obtaining a divorce permit from the superior, the application for divorce is then submitted to the Religious Court. If in the case process at the Religious Courts it turns out that the civil servant who wants to get a divorce has not obtained a divorce permit from his superior, then the Court postpones the trial for six months to arrange for a divorce permit. The mediation effort is carried out by the Regional Civil Service Agency and the Religious Courts to find a middle way so that divorce does not occur.

\section{REFERENCES}

Abdurahman. Kompilasi Hukum Islam di Indonesia. Jakarta: Akademi Presindo, 1992.

Ahmad Muhammad al-Sissal, et.al. Sistem Prinsip Dan Tujuan Ekonomi Islam, Bandung: C.V Pustaka Setia, 1999.

Abu Daud. Sunan Abu Dawud Kitab alAqdiyah, Bab fi Karahiyah al-Talak, Vol. 6, Beirut: Daar Al-Fikr, 1994.

Al-Asqar, Umar Sulaiman. Pernikahan Syar'I (Menjaga Harkat dan Martabat Manusia), Jakarta Timur:Sinar Grafika, 2012.
Ali Shu'aib, An-Nasa'i Ahmad bin. Sunan al-Nasa'i. Vol. 5. Lebanon: Dar alKutub al-ilmiyah.

Alhafidz Ahsin W. Kamus Figh. Jakarta: Amzah, 2013.

al-Hayati Kamil. Solusi Islam dalam Konflik Rumah Tangga. Jakarta: Raja Grafindo Persada, 2005.

Ali. Zainuddin. Metode Penelitian Hukum.Jakarta: Sinar Grafika, 2010.

Arifin, Imron. Penelitian Kualitatif, Bandung: Kalimasahada Press, 1996.

Arikunto, Suharsimi. Prosedur Penelitian Suatu Pendekatan Praktek. Jakarta: Rineka Cipta, 1998.

Al-Subkhi, Ali Yusuf. Figh Keluarga. Jakarta: Amzah.

Basyir. Ahmad Azhar. Hukum Perkawinan Islam, Yogyakarta: UII Press, 2000.

Bailey Kanneth D. Methods of Social Research. New York: A Division of Macmillan Publishing Co. Inc, 1982.

Basyir. Ahmad Azhar. Hukum Perkawinan Islam. Yogjakarta: UII Press, 1998.

Abu Dawud. Sunan Abu Daud Kitab alAqdiyah, Bab fi Karahiyat al-Talak. Vol. 6. Beirut: Daar Al-Fikr, 1994.

Departemen R.I Kompilasi Hukum Islam,(Jakarta: Dirjen Pembinaan Kelembagaan Agama Islam, 2000.

Djamil. Latif. H.M, Aneka Hukum Perceraian di Indonesia, Ghalia: Indonesia, 1985.

Emil Salim. Perencanaan Pembangunan dan

Pemerataan Pendapatan Jakarta: Yayasan Idayu, 1980.

Farida, Anik, et.al. Perempuan dalam Sistem Perkawinan dan Perceraian di Berbagai Komunitas Adat. Jakarta: e-ISSN: 2715-4580 p-ISSN: $2715-8268$ 
International Journal of Contemporary Islamic Law and Society

Vol. 3 No. 1 Tahun 2021

Balai Penelitian dan Pengembangan Agama Jakarta, 2007.

Fuady Munir. Konsep Hukum Perdata. Jakarta: Raja Grafindo Persada, 2014.

Furchan Arif. Pengantar Metode Penelitian Kualitatif. Surabaya: Usaha Nasional, 1992.

Ghozali, Abdul Rahman. Fiqh Munakahat. $3^{\text {rd }}$ Edition, Jakarta: Kencana, 2008.

Hadikusuma Hilman. Hukum Perkawinan Adat dengan Adat Istiadat dan Upacra Adatnya. Bandung: Cipta Aditya Bakti, 2003.

Ibnu Hajar al Asqalani. Bulugh al-Maram min Adillat al-Ahkam. Semarang: Toha Putera, nd.

Idhamy, Dahlan. Azas-azas Fikih Munakahat, Hukum Keluarga Islam. Surabaya: Al-Ikhlas.

Iqbal, Muhammad, Rusli, Rusli, \& Musyahidah, Musyahidah. (2019). "Management Strategies of Professional Zakat Funds for Mustahiq Family Welfare By Amil Zakat Body". International Journal of Contemporary Islamic Law and Society, 1(1), 39-51.

Jamali R Abdul. Hukum Islam Berdasarkan Ketentuan Kurikulum Konsorsium Ilmu Hukum. Bandung: Mandar Maju, 2003.

Pusat Bahasa Depertemen Pendidikan Nasional. Kamus Bahasa Indonesia, Jakarta: Pusat Bahasa, 2008.

Manan Abdul. Aneka Masalah Hukum Perdata Islam Di Indonesia. Jakarta: Kencana, 2008.

Michail P. Todaro. Pembangunan Ekonomi di Dunia Ketiga. Jakarta: Erlangga, 1994.
Moleong Lexy. Metode Penelitian Kualitatif. Bandung: PT. Remaja Rosda Karya, 2002.

Mugniyah, Muhammad Jawad. Figh Lima Mazhab. Jakarta: Lentera,1996.

Muhammad Abdul Kadir. Hukum Perdata Indonesia. Bandung: Citra Aditya Bakti, 2000.

Muhammad bin Ismail al-Amir alShan'ani. Subulus Salam. Terj. Vol.3. Jakarta: Darus Sunah Press, 2013.

Mubarok, Jaih. Peradilan Agama di Indonesia. Bandung: Pustaka Bani Quraisy, 2004.

Muslih, Imam, Nurdin, Nurdin, \& Marzuki, Marzuki. (2020). "Effectiveness of Marriage Services Through Information System Management (SIMKAH) at Palu City Religious Court" International Journal of Contemporary Islamic Law and Society, 2(1), 20-35.

Napirin, Pengatar Ilmu ekonomi, Makro dan Mikro, $1^{\text {st }}$ Edition.Yogjakarta: BPFE, 2000.

Neuman, W. Lawrence. Social Research Methods (Qualitative and Quantitative Approaches), $5^{\text {th }}$ edition. Boston: Allyn and Bacon, 2003.

Nurdin, Nurdin. (2019). Knowledge Integration Strategy in Islamic Banks. In Almeida Helena \& Sequeira Bernardete (Eds.), The Role of Knowledge Transfer in Open Innovation (pp. 118-138). Hershey, PA, USA: IGI Global.

Nurdin, Nurdin, \& Yusuf, Khaeruddin. (2020). Knowledge management lifecycle in Islamic bank: the case e-ISSN: 2715-4580 p-ISSN: 2715-8268 
of syariah banks in Indonesia. International Journal of Knowledge Management Studies, 11(1), 59-80. doi: $10.1504 / \mathrm{ijkms.2020.105073}$

Pasal 2 Kitab Undang-Undang Hukum Perdata.

Peraturan Pemerinta RI Tahun 2010, Tentang PNS, Citra Umbara, Bandung, 2010.

Peraturan Pemerintah Republik Indonesia No. 10 Tahun 1983 Tentang Izin Perkawinan Dan Perceraian Bagi Pegawai Negeri Sipil.

Prawirohamidjojo. R. Soetojo. Sejarah Perkembangan Hukum Perceraian di Indonesia Belanda, Surabaya: Airlangga University Press 1996.

Prijarminto Soegeng, Duri dan Mutiara dalam Perkawinan PNS, Jakarta: Pradyna Paramita, 1992.

Putusan Mahkamah Agung Nomor 121 K/AG/2011.

Putusan Pengadilan Agama Serang 0137/ Pdt.G / 2012 /PA.

Putusan Mahkamah Agung Nomor 184 $\mathrm{K} / \mathrm{Ag} / 2015$.

Qadrawi Yusuf, Hadyul Islam, Fatawa Nua'asyirah, Terj. As'ad Yasin, "Fatwa-fatwa Kontemporer", Vol. 1. Jakarta: Gema Insani Prees, 1995.

Raharjo Satjipto, Ilmu Hukum, Bandung: Citra Aditiya Bakti, 2000.

Rohman Abdur Al-Jaziri, Kitabul Fiqh Ala Madzahibil Arba, Beirut: Daarul Kutub Al-Ilmiyah, 1996.

Rasjid Sulaiman, Figh Islam, Bandung: Sinar BaruAlgensindo, 2014.

Rusli Rusli, Islamic Feminism: Responses of Muslim Feminists to Gender
Inequality in Indonesia (Palu: Irshed Press, 2006)

Rusli Rusli, "An Analysis of Islamic Feminism in Indonesia: Reconstruction of Islamic Legal Issues on Gender Relations," Hunafa: Jurnal Studia Islamika 3, no. 1 (2006): 1-12.

Rusli Rusli, "Al-Juwaini Dan Konsep Maqashid Syari'ah Telaah Kitab Al-Burhan Fi Usul Al-Fiqh," Istinbath: Jurnal Hukum 9, no. 2 (2013).

Rusli Rusli, "Wahhabi Salafism's View on Maqasid Al-Syariah," AlManahij: Jurnal Kajian Hukum Islam 8, no. 2 (2014): 167-180.

Rusli Rusli, Nalar Fikih Tradisionalis Progresif: Analisis Terhadap Epistemologi Ibrahim Hosen, 1st ed. Yogyakarta: Maghza Books, 2014.

Rusli, Rusli, "Hermeneutical Reading of Ṭalāq," HUNAFA: Jurnal Studia Islamika 12, no. 2 (2016): 209-229.

Rusli Rusli, "The Role of Family in Preventing Social Conflict in Society From Islamic Perspectives," HUNAFA: Jurnal Studia Islamika 17, no. 1 (2020): 108-122.

Rusyd Ibnu. Bidayat al Mujtahid Wa Nihayat al Muqtasid. Vol. 2, Beirut: Dar al-Jil, 1989.

Sabiq Sayyid, Fikih Sunnah juz 8, Bandumg: PT. Alma Arif, 1987.

Salim, HS. Pengantar Hukum Perdata Tertulis. Jakarta: Sinar Grafika, 2006.

Shalih bin Ghonim as Sadlan, Kesalahankesalahan Istri. Jakarta: Pustaka Progesif, 2004. 
Sudarsono. Hukum Perkawinan Nasional, Jakarta: PT. Rineke Cipta, 1991.

Sudarsono, Hukum Perkawinan Nasional, Jakarta: PT Rineka Cipta, 2009.

Sugiyono, Metode Penelitian Pendidikan Pendekatan Kuantitatif, Kualitatif, dan $R \mathcal{E} D, 6^{\text {th }}$ Edition. Bandung: Alfabeta, 2008.

Sukaenah, Sukaenah, Rusli, Rusli, \& B, M. Taufan. (2020). The Effectiveness of Indonesia Supreme Court Regulation Number 1 Year 2016 Concerning Mediation of Marriage Disputes International Journal of Contemporary Islamic Law and Society, 2(1), 63-80.

Sulaiman bin al Asyas al Sijistani, Sunan Abu Dawud. Vol. 1. Beirut: Dar al Kutub al Ilmiyah 1996.

Sunhaj Ahmad, Teknik Penulisan Kualitatif dalam Penelitian Kualitatif dalam Ilmu-Ilmu Sosial dan Keagamaan. Malang: Kalimasada Press, 1996.

Sya'bi. Akhmad, Kamus Al-Qolam (ArabIndonesia, Indonesia-Arab). Surabaya: Halim Jaya.

Syaifuddin Muhammad, et.al. Hukum Perceraian. 2nd Edition. Jakarta: Sinar Grafika, 2014.

Syarifudin Amir, Garis-garis Besar Figh. Jakarta: Prenada media group, 2003.

Tihami dan Sahrani Sohari, Fikih Munakahat Kajian Fikih Nikah Lengkap, Jakarta: PT. Raja Grafindo Persada, 2014.

Tim Al-manar, Fikih Nikah, Bandung: Syamil Cipta Media, 2007.

Tim penyusun Kamus Pusat Pembinaan dan Pengembangan Bahasa,
Kamus Besar Bahasa Indonesia Edisi Kedua (Jakarta: Balai Pustaka, 1997), 185.

Usman Husaini dan Akbar. Purnomo Setiadi, Metodologi Penelitian Sosial, Jakarta: PT Bumi Aksara, 2009.

Widjaja. A.W, Administrasi Kepegawaian, Jakarta: Rajawali, 2006.

Wipress, Peraturan pemerintah tentang PNS, wacana intelektual, 2007.

Wahyu Ramdani, Administrasi Islam di Indonesia, Bandung, n.p., 2011.

Yunus Mahmud, Hukum Perkawinan Dalam Islam, Jakarta: PT. Hidakarya Agung, 1983.

Yunus, Haerunnisa, Rusli, Rusli, \& Abidin, Abidin. (2020). The Concept of A Marriage Agreement in the Compilation of Islamic Law International Journal of Contemporary Islamic Law and Society, 2(2), 35-45.

Zuriah Nurul, Metodologi Penelitian Sosial dan Pendidikan Teori-Aplikasi Jakarta: PT Bumi Aksara, 2009. 